\title{
The paradoxes of informalizing street trade in the Latin American city
}

Lissette Aliaga Linares

\author{
Department of Sociology and Anthropology, University of Nebraska at Omaha, \\ Omaha, Nebraska, USA
}

Received 29 September 2017 Revised 22 February 2018 Accepted 22 February 2018

\begin{abstract}
Purpose - The purpose of this paper is to challenge the default portrayal of street trade as an informal occupation and spatial practice, by examining comparatively the changes in the regulatory frameworks of two politically distinct city administrations in Latin America since the introduction of the informal economy debate.

Design/methodology/approach - This paper draws from a comparative case study design to synthesize evidence from historical administrative records, secondary research and materials from a two-year fieldwork carried out in Lima and Bogotá in 2008 and 2009.

Findings - The author argues that the incorporation of the informal economy framework into local governments' policymaking has reframed street trade as a subject of policy. Since the 1970s, the author traces a shift from worker-centered initiatives, through the deregulation of street trade, to entrepreneurial-centered approaches. Nowadays, both, Lima's neoliberal governance focusing on "formalizing" and Bogotá's socialist/progressive governance aiming at "upgrading" street trade respond more explicitly to distinct assessments about the informal economy - legalist and dualist, respectively. Yet, both cities converge in that the closer street trade is perceived as an informal occupation; the more likely policy initiatives decouple the right to work from the right to access public space, spurring more marginal forms of street vending.

Originality/value - Even though the informal economy framework has helped to draw attention to important policy issues locally, nationally and internationally, this paper calls for a critical revision of such framing at the local level to allow for inclusive urban governance.
\end{abstract}

Keywords Latin America, Informal economy, Public space, Petty trade

Paper type Research paper

\section{Introduction}

A Google image search using the term "informal economy" renders more pictures of street vendors than of any other occupation. Compared to off-the books factory or home-based workers, street vendors, however, are not always the largest informal-worker group across cities of the developing world, although it represents an important source of employment for urban poor women[1]. Given its marginal status as an occupation, the links between street trade and the informal economy are undeniable. Yet, this connection has also influenced the way scholars and policy makers conceptualize this occupation, which has important implications for shaping the local policy environments of street vendors.

The informal economy refers to a wide range of low-productivity occupations that either lack adequate social protection or fail to comply with business regulations. Scholars had

C) Lissette Aliaga Linares. Published by Emerald Publishing Limited. This article is published under the Creative Commons Attribution (CC BY 4.0) licence. Anyone may reproduce, distribute, translate and create derivative works of this article (for both commercial \& non-commercial purposes), subject to full attribution to the original publication and authors. The full terms of this licence may be seen at http:// creativecommons.org/licences/by/4.0/legalcode

The author is thankful for the research support of the Inter-American Foundation. An early version of this paper was discussed at the Conference "Contesting Streets II: Vending and Public Space in Global Cities" organized by the University of Southern California. The author is grateful for the insightful comments that participants of the conference were able to share to the initial manuscript and subsequent comments of Dr. Bryan Roberts.

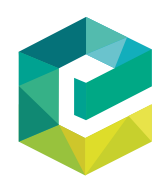

International Journal of Sociology and Social Policy Vol. 38 No. $7 / 8,2018$ pp. $651-672$ 
IJSSP

$38,7 / 8$

652

repeatedly criticized this definition for its analytical flaws (Breman, 1976; Peattie, 1987; Morales, 1997, 2001). But as scholars continue to study the informal economy, street trade has gained popularity as either a shortcut for the unregulated economy or a testing ground to explore the limits of state enforcement. As early as the 1970s, scholars studied street trade to theorize about the links between the informal and the formal economy (Bromley, 1978), the informal economy connections to urban poverty (Teltscher, 1994; Steel, 2008) and the role of regulation (Contreras and Thomas, 1993; De Soto, 2002). Case studies on street trade have highlighted the social and political consequences of "informal" politics in the region (Cross, 1998a, b; Crossa, 2009; Garcia Rincon, 2010) and, just recently, lenient policy responses toward street vendors have been conceptualized by political scientists as a form of "informal" welfare (Holland, 2016).

These informal economy studies have served to gain insights on street trade by analyzing its heterogeneity and politics of enforcement; however, scholars have rarely addressed how framing street trade as an informal occupation has affected its regulatory environment. Recent single-city and cross-sectional case studies have shown that the informal label is more explicit in current regulations (Roever, 2006) and in official public discourse (Hunt, 2009). Given the divergent urban political regimes in Latin America (Goldfrank and Schrank, 2009) and the competing perspectives that have dominated the informal economy debate at different times (Portes and Schauffler, 1993; Rakowski, 1994; Biles, 2009), more comparative and historical studies are needed to understand the conditions by which local governments used different informal economy theorizations to frame policy toward street vendors.

Through a comparative case study of two contrasting political regimes-neoliberal Lima and socialist Bogota, I argue that, rather than being an inherent trait of this occupation, the framing of street trade as an informal occupation has primarily responded to different priorities of development, stages of urbanization and political changes in local governance. Despite academic evidence challenging former assumptions of the dominant theorizations of the informal economy, I demonstrate how local governments have continued to use the basic tenets of these theories to validate their regulatory approaches - particularly the dualist and legalist but influenced as well by the structuralist and voluntarist[2]. Regardless of the informal-economy perspective used in contemporary local policy frames and the push for more comprehensive policies at the international level, the use of these assumptions suggests that the increasing visibility of street trade as a subject of policy through the informal label — what I call its "informalization" - has fostered its local delegitimation as a spatial and economic practice within neoliberal and socialist/progressive contexts.

I start by revising the connections between street trade and informality in the policy-oriented and scholarly literature. The next section describes the methodology. Then, I analyze policy frames attending to three critical urban transition: the period from the 1970s to end of the 1980s, when most Latin American economies adopted the Import by Substitution Industrialization (ISI) development model and the informal economy debate started; the early 1990s, when the structural adjustment policies fostered labor-market deregulation and economist Hernando de Soto's legalist approach challenged previous casual relationships about the informal economy; the 2000-2010 period, when Latin America consolidated as a free-market economy and many international development agencies agreed upon the need to formalize the informal sector. In each of these periods, I examine the social contexts by which local policy frames aligned with particular theoretical assessments of informality. Finally, I summarize the findings and discuss their practical and theoretical implications.

\section{The informal economy debate and street trade in Latin America}

Street vendors represent from 5 to 10 percent of the total employed population across Latin American cities (Roever, 2010) as an economic practice and subject of policy, street trade 
precedes the informal-economy debate in Latin America. In some cities, selling or bartering in open-air plazas and broadly defined public spaces can be traced to pre-Hispanic times (Hirth and Pillsbury, 2013). Ordinances and decrees regulating, prohibiting and enacting evictions have been documented as early as colonial times (Ghersi et al., 1998; Salazar, 2004; Chavez and la Flor, 1998). But it was not until the mid-twentieth century that street trade gained visibility as a social problem beyond public-order concerns. I will argue that the concept of the informal economy made street trade a subject of scholarly research and increased its visibility as a subject of development policy.

The connection between street trade and what would later be labeled informal sector dates to the 1960s with debates surrounding urban marginality. The contrasting development of a modern industrial sector alongside sprawling slums and a growing marginal workforce in Latin American cities was part of the early sociological and economic debates in the region. Whereas Germani's (1968) marginality theory argued that the failure to incorporate rural migrants to modern urban institutions prevented widespread social modernization in Latin America, Marxist dependency theorists referred to this marginal workforce as permanent by-product of dependent capitalist development (Quijano, 1969; Nun, 1969). Based on these dualistic conceptualizations, occupational analysis of urban marginal employment included street vendors (Lambert, 1965; Alessio, 1970) but they were not studied in detail.

During the 1970s, although marginality debates and critiques continued (See e.g. Perlman, 1976), the concept of the informal sector rapidly gained popularity for its potential to articulate existent employment policy initiatives promoted by the International Labor Organization (ILO). Keith Hart (1973), an economic anthropologist, used the term "informal sector" to refer to illegitimate and legitimate income-generating activities performed by the urban poor in Accra, Ghana. Hart claimed that informal economic activities had the potential to provide economic opportunities for the jobless and reduce the earnings gap for the underemployed. His conclusions echoed some of the recommendations drafted earlier in the ILO-Regional Employment Programme for Latin America and the Caribbean for Colombia, which noted the dilemma of focusing exclusively on economic growth in the modern sector to promote employment (Peattie, 1987). Following the diagnosis of dependency theorists who equated the informal sector to the low-productivity sector, (Prebisch, 1962; Pinto, 1970), the general focus was to use policy toward this sector to promote equity within goals of economic growth through industrialization (Peattie, 1987; Nuñez Castrejón and Gómez Chiñas, 2008).

Scholars initially claimed that the segmentation between formal and informal distorted the comprehension of urban economies (Breman, 1976; Sethuraman, 1976; Moser, 1978). As research on the informal sector followed, street trade provided a case study that challenged dualistic theorizations. In a pioneer study, Bromley (1978) examined the employment structure and social organization of street vendors in Cali, Colombia. He found that street trade presented an internal heterogeneity that questioned the default assumption of informal economic activities as truly independent economic activities unconnected to the formal sectors of the economy. Indeed, he found that a sizable proportion of vendors worked as commission sellers or had dependent relationships with suppliers of merchandise that produced goods in the formal sector. The analysis of street trade highlighted the links between formal and informal enterprises, which resulted in different employment relations.

Between the 1980s and the 1990s, definitional critiques of the informal sector continued (Papola, 1980; Peattie, 1987). However, research- and policy-expertise discussions reached a wider interdisciplinary audience, from international development agencies to local non-profit organizations and think tanks (Rakowski, 1994). At this time, changing economic conditions born of the Latin American structural adjustment and austerity fiscal reforms increased unemployment, making evident the declining opportunities in the formal sector and lack
Paradoxes of informalizing street trade

653 
IJSSP

$38,7 / 8$

654

of elasticity to cushion the effects of the informal sector[3]. Some of these trends were exemplified in street trade studies. Unlike previous characterizations that linked the informal workers with "secondary" workers (Mazumdar, 1976) Contreras and Thomas (1993) found that most street vendors in Santiago de Chile were heads of households, usually unemployed men, for whom street trade was the main source of income. Their study was the first to emphasize the role of regulation. They argued that restrictive policies provided greater incentive for police harassment, resulting on limited capital accumulation among street vendors.

As the Latin America's economy opened to international trade, poverty rates soared. As a result, theorizations on the casual links of the informal economy expanded during the 1980s and 1990s. The structuralist/neo-Marxist approach conceptualized the informal economy as a global phenomenon explained by shifts in the expansion of capitalism (Castells and Portes, 1989). Because of developed countries' outsourcing, subcontracting expanded to the developing world. As local economies in Latin America restructured to sustain the growth and profits of capitalist industries in developed regions, labor marginalization deepened. Structuralist theorizations largely analyzed changes in the manufacturing sector, but street trade studies followed as well. Teltscher (1994) found that the subordinate role of street trade within global and national supply chains translated into differences in capital accumulation among street vendors in Quito, Ecuador. Most advantaged vendors were able to import directly foreign products that required high capital investment. In contrast, those who were trading indirectly national products, which required little capital investment, faced greater competition and low returns.

Unlike the structuralist standpoint, focused on the expansion of capitalism as fueling the informal economy, the legalist or De Soto approach argued state's over-regulation inhibited capitalist gains from filtering down to the urban poor (De Soto et al., 1986). According to De Soto's study of informal trade in Lima, the daily tax collected by local governments entitled street vendors to special ownership rights on the street and slowed down the pace by which street vendors were moving to roofed markets (De Soto, 2002, p. 91). In his analysis, the existent regulation equated to extralegality - a non-state based regulatory environment that prevented street vendors to reach their entrepreneurial potential. Although his data did not substantiate the claim of a slowdown in vendors' construction of roofed markets[4], De Soto and his collaborators advocated that the state should simplify regulations to encourage street vendors' transition to roofed markets.

Along with the wealth of empirical research, the ILO renewed its focus on the informal economy and influential agencies such as the World Bank (WB) positioned on this debate. The ILO redefined measurement guidelines for informal enterprises and informal jobs (ICLS 15th, 1993, ICLS 17th, 2003), incorporated regulatory environments as contextual factors in analyzing the informal economy (Tokman, 1990), and called for the active role of the State in promoting equitable labor policies and accommodating survival enterprises through heterogeneous strategies (Tokman, 1989). Between 2000 and 2010, the WB added the voluntarist approach to the above three theorizations (Perry et al., 2007). This approach characterizes the informal economy in Latin America as a voluntary unregulated small-firm sector (Maloney, 2004), in which informal entrepreneurs and workers weigh the costs and benefits of formality. In this perspective, non-compliance results from a continuum, in which at one extreme, there are situations of exclusion, but in the other, workers and entrepreneurs prefer to avoid regulation (Perry et al., 2007).

In recent years, the ILO and the WB have convened in promoting the transition from the informal to the formal economy through differential approaches. The ILO pioneers a rights-based approach that coincides with the need for equitable policies claimed by structuralists. For instance, the ILO Recommendation No. 204 Concerning the Transition from the Informal to the Formal Economy provides a set of guidelines for governments to promote formalization within the principles of decent work and inclusive development, 
including the implementation of stable regulatory frameworks for street vendors (ILO, 2015) and has published a compilation of best practices (ILO, 2016). In contrast, the WB promotes an economic growth-based model that focus on initiatives encouraging formal entrepreneurship. For informal trade as a whole, WB's concerns focus on keeping an attractive economic climate for investors and reducing unfair competition (Benjamin et. al., 2014) through administrative simplification and cost reduction for business registration (Sislen et al., 2007). Although street vending is not a WB target policy group, this agency has commissioned studies on this sector (Mitullah, 2003) and their pro-business initiatives and urban initiatives have influenced street trade policy in many cities in the developing world (Lyons and Titus Msoka, 2010).

Within the informal economy framework, street trade is more than an ordinary occupation. Its prevalence have come to represent a faulty sign of uneven development, one that is mostly explained by the need for employment and the corresponding lack of adequate options to work or start a business. Yet, none of the major theorizations captures all the various motives why people engage in this occupation (Williams and Gurtoo, 2012) or offer substantive guidelines to formulate adequate regulations (Chen, 2007, pp. 9-10). Nonetheless, as the informal economy debate frame international commitments and national policy, these assessments translate into local regulations. This paper will address how informality assessments have historically been used to frame regulation approaches toward street trade, the context by which these frames gained institutional support and state integration, and whether they have served to validate either exclusionary or inclusive policies in Latin America.

\section{Methods}

In addition to newer developments regarding the informal economy debate, the transition from ISI to a free-market economy has also brought about significant changes in Latin American cities. This transition contributed to a rise in open unemployment, informal employment - as measured by lack of social security protection, income inequality, and crime victimization rates (Portes and Roberts, 2005), which have intensified the tensions among users of public space (Sabatini, 2006; Caldeira, 2000). While across Latin America these urban changes vary only in degree, political responses have resulted in divergent urban policy regimes. Goldfrank and Schrank (2009) identify two poles of these regimes in the region, socialist and neoliberal, which formed as a response to the free market transition. Most governments in the region incorporate some aspects of these two policy regimes, as municipal authorities try to balance the need to integrate into the global economy and the internal demands of their constituents. Yet, the differences in emphasis can significantly influence the political process by which authorities frame street trade policies.

To sample the convergence in urban trends and divergence in urban regimes in the region, I examine the changes in local policy frames toward street trade in Lima and Bogota from the 1970s to the end of 2010. Both cities share similar trends and characteristics regarding informal employment[5], residential segregation[6], and have underwent successful historic-center recovery in the mid-1990s. Between 2005 and 2010, these two cities exemplify the divergence in urban regimes (Goldfrank and Schrank, 2009). Lima's policy corresponds to the municipal neoliberalism which prioritizes accumulation using regulatory rollbacks as a means to attract foreign investment and Bogotá' falls within the municipal socialism prioritizing redistribution and therefore implement policies to democratize the use of public funds and other compensatory mechanisms. This contrast of contexts permits to examine how parallel processes of urban change incorporate divergent assessment of the informal economy in urban governance.
Paradoxes of informalizing street trade 
IJSSP

$38,7 / 8$

656

The empirical evidence draws from a combination of sources in these cities: metropolitan street vending ordinances and laws from the mid-1970s to 2010, historical censuses and household surveys-based estimations of street vendors[7], local archival research and 64 semi-structured interviews - 54 policymakers at different governmental dependencies and 10 key informants - conducted in Lima and Bogotá during 2008 and 2009. Key informants were selected using snowball sampling to identify local leaders in the street vending sector and other commerce-based organizations in both cities. Public officials and policymakers were contacted after compiling a list of institutions in each city that formulate policy toward street vendors. Out of 54 interviews, 33 correspond to local, 11 to metropolitan and 10 to national agencies. Interviews lasted from 45 minutes to an hour and were recorded when permitted. Audios and notes were transcribed, coded and analyzed using NVIVO. I traced vertically how the framing of street trade aligned with national policy agendas in each city and horizontally how these frames matched the urban patterns in both cities. Nonetheless, given the focus on social contexts for this paper, interviews are presented in an analytical narrative rather than a detailed exploration of public officials rationales for policymaking. Table I summarizes the findings of the comparative case study over three critical urban transitions. I will describe these findings in detail in the following sections.

\begin{tabular}{|c|c|c|c|c|c|c|}
\hline & \multicolumn{2}{|c|}{$\begin{array}{l}\text { ISI } \\
\text { From } 1970 \text { s to mid-1980s }\end{array}$} & \multicolumn{2}{|c|}{$\begin{array}{l}\text { Structural adjustment } \\
\text { From mid-1980s to end of } 1990 \text { s }\end{array}$} & \multicolumn{2}{|c|}{$\begin{array}{l}\text { Free market city } \\
\text { From } 2000 \text { to } 2010\end{array}$} \\
\hline & Lima & Bogota & Lima & Bogota & Lima & Bogota \\
\hline \multicolumn{7}{|c|}{ Institutional alignment relevant to informal economy framework } \\
\hline International & Dualist & Dualist & Dualist/Legalist & Dualist/Legalist & $\begin{array}{l}\text { Dualist/ } \\
\text { structuralist/ } \\
\text { Legalist/ } \\
\text { voluntarist }\end{array}$ & $\begin{array}{l}\text { Dualist/ } \\
\text { structuralist/ } \\
\text { Legalist/ } \\
\text { voluntarist }\end{array}$ \\
\hline National & Dualist & Dualist & Legalist & Dualist & $\begin{array}{l}\text { Legalist/ } \\
\text { voluntarist }\end{array}$ & $\begin{array}{l}\text { Dualist/ } \\
\text { structuralist }\end{array}$ \\
\hline Local & Dualist & Dualist & Legalist & Legalist & $\begin{array}{l}\text { Legalist/ } \\
\text { voluntarist }\end{array}$ & $\begin{array}{l}\text { Dualist/ } \\
\text { structuralist }\end{array}$ \\
\hline $\begin{array}{l}\text { Urban Policy } \\
\text { Regime }\end{array}$ & Socialist & Socialist & Neoliberal & Neoliberal & Neoliberal & Socialist \\
\hline Urban context & Favorable & Favorable & Less favorable & Less favorable & Unfavorable & Unfavorable \\
\hline \multicolumn{7}{|c|}{ Municipalities' enforcement capacity of street trade policy } \\
\hline Regulatory intent & Organize & Organize & Relocate/Evict & Relocate/Evict & Formalize & Upgrade \\
\hline $\begin{array}{l}\text { Resources for } \\
\text { control/policy } \\
\text { implementation }\end{array}$ & Low & Moderate & High & High & High & High \\
\hline State integration & High & High & High & High & High & Moderate \\
\hline \multicolumn{7}{|c|}{ Street trade policy components } \\
\hline Spatial regulation & $\begin{array}{l}\text { Zoning/ } \\
\text { taxing }\end{array}$ & $\begin{array}{l}\text { Zoning/ } \\
\text { Licensing }\end{array}$ & Restricted & Restricted & $\begin{array}{l}\text { Restricted } \\
\text { zoning and } \\
\text { licensing }\end{array}$ & $\begin{array}{l}\text { Restricted } \\
\text { zoning and } \\
\text { licensing }\end{array}$ \\
\hline $\begin{array}{l}\text { Social integration } \\
\text { initiatives }\end{array}$ & $\begin{array}{l}\text { Scarcely } \\
\text { implemented }\end{array}$ & $\begin{array}{l}\text { Scarcely } \\
\text { implemented }\end{array}$ & Suspended & Suspended & Conditional & Conditional \\
\hline $\begin{array}{l}\text { Political } \\
\text { Participation }\end{array}$ & Encouraged & Encouraged & Suspended & Suspended & Conditional & Conditional \\
\hline $\begin{array}{l}\text { Street vendors' } \\
\text { organizational } \\
\text { response }\end{array}$ & Unionization & Unionization & Fragmentation & Fragmentation & Fragmentation & Fragmentation \\
\hline \multicolumn{7}{|c|}{ Street trade policy outcomes } \\
\hline $\begin{array}{l}\text { Trends in the } \\
\text { number of street } \\
\text { vendors }\end{array}$ & Increase & Increase & Decrease & Decrease & Maintain & Decrease \\
\hline
\end{tabular}

Table I.

Contextual variables to compare Lima and Bogota changes in street vending policy across city's stages 


\section{Urban transitions and street trade policy in Lima and Bogota}

\subsection{The ISI city and street trade worker-centered initiatives}

During ISI, the national efforts to promote industrialization neglected to address locally the growing informal sector. As industrialization sought to modernize the economic structure, policymakers expected that many of these informal activities - including street vending - will eventually disappear. In addition, up to the mid-1980s in Latin America, the president appointed city mayors and national ministries administered municipal budgets, leaving local municipalities with very little political autonomy and few resources to implement policies. Alongside the dualist approach to the informal economy, street trade was perceived as a structural problem. In this context, street-trade policies were mostly concerned with publicorder concerns, regulating access to public space through either licensing or taxation. As mayoral political agenda evolved in tune with that of national leaders and political parties, the administration of such regulations allowed for political clientelism and increased the influence of street vendors' organizations.

Added to the priorities of national and local development agendas, the unprecedented growth of Latin American cities that followed industrialization also contributed to the increase of the number of street vendors. On the one hand, street trade offered a source of employment for many rural migrants and some locals who could not land those "protected" industrial jobs. On the other hand, street trade became a source of "opportunity," as established commercial stores, which were usually located in upper-middle class neighborhoods, failed to satisfy the need for cheap goods of a large low-income population and to supplement the needs of a rather economically fragile middle class.

Geopolitically and economically street trade in Lima and Bogotá became central in the commercial distribution of the ISI city. As the commercial infrastructure concentrated mostly within old neighborhoods in the center of the city, from which the upper and middle classes fled early in the nineteenth century, large open-air markets sprang up in many central locations in Lima and Bogotá. Street trade also expanded within squatter settlements in the outskirts of the city, where many low-income population and migrants lived. It expanded the commercial distribution of domestic products - and even foreign products [8] - in both cities. Osterling and Chavez de Paz (1979) found that in addition to manufactured goods from formal retailers, most of the products sold by street vendors in downtown Lima came from small artisan workshops, which constituted the majority of the city's industrial sector. In the case of Bogotá, many studies found that "patrones" or formal businesses usually acted on behalf of street vendors to purchase licenses on the condition of selling their products (Nelson, 1992; Lanzetta de Pardo et al., 1988).

While the urban conditions facilitated the increase of street trade, the political economy of ISI contributed to advancing the political organization of street vendors. The ISI model relied on the role of the state to mediate the relationship between capital and labor. Welfare systems benefited exclusively wage-workers in medium and large industries in the private as well as in the public sectors, leaving out the self-employed, family unpaid workers, domestic servants, as well as small entrepreneurs and their workers. Correspondingly, local authorities tolerated street vendors, but several social protection issues were not part of local policies.

In Lima, while the majority of street vendors organized locally to defend their use of public space, some associations started to diverge in purpose. For instance, associations of better-off vendors organized within workers' cooperatives to enable self-relocations to roofed markets. Scaling up, a sector of these street vendors founded the Asociación Nacional de Vendedores Ambulantes del Perú (ANVAP) in 1975. Meanwhile, a large sector of street vendors with lower earnings unionized to defend their use of public space in Comité para la Unificación y Organización de los Vendedores Ambulantes del Perú (CUNOVAP). In 1979, a federation claiming to represent local organizations across Metropolitan Lima Federación Departamental de Vendedores Ambulantes de Lima (FEDEVAL) emerged from CUNOVAP.
Paradoxes of informalizing street trade 
IJSSP

$38,7 / 8$

658

Osterlling and Chavez de Paz (1979, pp. 198-200) found that these organizations had different diagnoses of street vending. While ANVAP argued that street vending was a temporary problem to be "solved" by relocations, CUNOVAP argued that street vending was a structural problem caused by lack of employment opportunities. FEDEVAL agreed with CUNOVAP but added a Marxist interpretation, defining street vendors as part of the proletariat exploited by the national bourgeoisie[9].

In Bogotá, street vendors' unionization also peaked during the 1970s. For instance, Sindicato Nacional de Unidad de Comerciantes Menores (SINUCOM) supported the Movimiento Obrero Independiente y Revolucionario (MOIR) and SINDEPEAC supported the Union Patriotica (UP). Even though paramilitary agents systematically assassinated UP party leaders, including many street vending leaders, during the 1970s (Donovan, 2002, p. 77), unionization kept growing, making SINUCOM and SINDEPEAC two of the largest street vendor unions, alongside with 60 associations (Nelson, 1992, pp. 286-287). Vote buying, particularly among city council representatives - who, unlike mayors, were elected citywide and came largely from the liberal versus conservative parties, became the main mechanism of political influence for street vendors (Donovan, 2002). Moreover, similar to the case of Lima, street vendors unions built alliances with other workers based on a shared assessment of their proletarianization, participating in the National Civic Strike of 1977 (Moralo Camargo, 2010).

The opening of city mayor elections during the 1980s further facilitated a political climate that increased the political influence of street vendors' unions. In Lima, vendors used their taxpayer status to advance legislation to allow for some social protection initiatives. After the election of Alfonso Barrantes (1983-1986), a leader of the left coalition Izquierda Unida, policies started to incorporate participatory practices that included street vending organizations. In 1985, with the approval of Metropolitan Ordinance 002, municipalities enabled street vending organizations to negotiate under an institutional form named the Mixed Technical Commission. The ordinance also established that 20 percent of street vendors' collection be invested in services of social protection for them. A program of campos feriales (street fairs) also enabled licensed street markets within municipal lands or public spaces. While compliance in other districts was not substantial in the whole city of 43 districts, street vendors still managed to use this provision to advance in negotiations. In Bogotá, the city government administrated licenses and created an administrative unit for that purpose in 1972. The Fondo de Ventas Populares (Popular Sales Fund, FVP in Spanish Acronyms) developed programs for specific type of vendors, including peddlers, stationary, and vendors in specialized trades. Prior to 1988, the FVP implemented many relocations but for the sake of improving sanitary conditions. Some of these off-street relocations failed, such as the case of San Victorino, due to the high costs of renting stalls. Gradually, FVP focused mainly on licensing and the need to secure licenses enabled a greater political influence of street vendors' organizations (Donovan, 2002).

In both cities, city governments mapped the city, negotiating with street vendors restricted and permitted zones and established policies to improve sanitary conditions. None of the ordinances, agreements or decrees that regulated street trade during this time used the term "informal" to refer to street trade. In Lima, despite the recurrent discursive use of the term "informal sector" as the population left behind in mayoral and presidential elections (Cameron, 1991), the Ordinance 002 never used the term "informal" to qualify street trade. In Bogotá, prior to 1986, the concept of "informal market" or "informal sector" was absent from the language used in regulations in the FVP.

During ISI period, street vending grew in Lima and Bogotá. In Lima, the National Institute of Statistics (INEI), estimated 58,284 street vendors in 1976, based on head-counts of 29 local municipalities. Using the same methodology, ten years later, the Institute Libertad y Democracia (ILD) estimated 94,231 street vendors. In 1986, INEI, based on 
employment statistics, estimated that four million people in Lima declared street vending as their main occupation in 1980, accounting for 10 percent of the economically active population in the city (Osterlling and Chavez de Paz, 1979). Likewise in Bogotá, the FVP counted 15,084 street vendors in the city in 1977, based on their registration accounts (Simanca Castillo, 2007, p. 34). In 1982, the National Institute of Statistics (DANE) estimated 58,347 street traders, which will roughly represent 3.5 percent of the working population in that city at that time.

\subsection{Structural adjustment and the deregulation of street trade}

During the 1990s, structural adjustment policies altered urban politics in Latin American cities. The privatization of state-owned enterprises, deregulation of the labor markets and the reduction of trade barriers required efficient local governments that could attenuate the impact of fiscal reforms. Added to the opening of city mayor elections in the mid-1980s, fiscal decentralization in the 1990s made local governments more proactive in increasing their tax base and attracting private investment. In this context, street trade's informality took a different connotation. Even though, unemployment rose and poverty soared, no longer was street vending perceived as an structural problem. Rather, they represented a local obstacle to enable widespread economic development and to secure municipal governance. A new wave of independent mayors dismantled the previous regulatory frameworks of street trade, enacted evictions and implemented relocations. The legalist approach to the informal economy became functional for fragmenting street vendors' organizations in the case of Metropolitan Lima, as well as, for gaining public support despite the limited success of previous relocation projects in Bogotá.

Additionally, the modernization of the retail sector undermined street vendors' central role over distribution. Bogotá's wholesale market relocation to the periphery at the end of 1970s had already contributed to the decline of farmers' markets in the downtown area by increasing transportation costs for small retailers, and fostered the expansion of supermarkets beyond the upper-middle class neighborhoods of the north (Moser, 1980). While Lima's wholesalers remained in downtown areas, supermarkets also started to reach peripheral neighborhoods in the early 1990s, despite their limited success. The recovery of public space also took center stage as means to promote international tourism and a sense of public order. The deterioration of Lima's historic center placed pressure on upcoming mayors given United Nations Educational Scientific and Cultural Organization nomination of this place as a worldwide patrimony.

Due to the public's discontent with traditional parties, the preferences for independent politicians in the mayoral elections of Lima and Bogota weakened the political influence of street vending unions and enabled large-scale evictions. In Lima, Mayor Alberto Andrade (1996-2002), a business man who ran as an independent, took office in 1996 and undertook 20 operations to evict street vendors (Roever, 2005, p. 80). Andrade suspended the collection of sisa in downtown Lima to force negotiations with street vendors' representatives. Twoyear agreements for relocation, even those vendors within already regulated spaces such as the Campo Ferial Polvos Azules were signed. Street vendors' organizations had this time to save funds for at least a down payment to purchase a property and build a commercial center. The city hired a large staff that kept vendors informed about spaces for sale, and were continuously supervising their internal decisions (Evans, 2005). After relocation, the city favored street vendors with two years exoneration of taxes. Street vendors with larger capacity for accumulation, particularly those who sell imported goods, were able to relocate. The city allocated only 2,000 temporary licenses to vulnerable vendors and given preference to the elderly. The recovery of Lima's historic center set the standard of policy for the other local municipalities. At the end of the 1990s, many municipalities within the central area of
Paradoxes of informalizing street trade 
IJSSP

$38,7 / 8$

660 the city replicated this approach, conducing to a massive eviction of vendors from within the middle class residential areas.

From 1995 to 2003, the independent Mayor Antanas Mockus (elected for two terms, 1995-1997 and 2001-2003), and Mayor Enrique Peñaloza (1998-2000), dismantled the licensing policies and initiated massive evictions through off-street relocation policies. Despite the unsuccessful experiences of previous relocation, these mayors were able to enforce their policies due to their greater control of political and fiscal resources. With decentralization, city mayors were given the power to appoint deputy mayors to serve in the 20 localities of Bogota, which meant greater control over political resources limiting the power of city and local council representatives. Due to better management for the collection of property taxes and new legislation that increased national transfers, Bogota's public revenue grew by 77 percent (Donovan, 2002, pp. 63-64). As a result, city government recovered "more than 1 million square meters of space, constructed or rehabilitated 1,500 parks, built nearly 40 enclosed markets with stalls for 5,000 former street vendors and invested more than US\$20 million in malls for relocated street vendors" (Donovan, 2008, p. 30). The strategies used to convince vendors relied mostly on educational technologies rather than on political negotiations. For instance, from 2001 to 2003, one-third of relocations were voluntary (Berney, 2011; Castañeda and Garcia, 2007). Yet, relocations were still unsuccessful. Only 7 out of 29 projects implemented in 1990s from previous administrations were active in 2008 (Castañeda and García, 2007, pp. 174-177).

The content of street trade's informality in both cities responded to new institutional configurations at the local and national level that fostered a more proactive role at controlling street trade. For the case of Lima, the national laws of decentralization, microenterprise development and employment promotion contributed to override Ordinance 002 (Roever, 2006). The Law of Decentralization of 1993 did not allow municipalities to collect sis $a$ as a form of tax. Nonetheless, many municipalities continued to collect sisa as a form of municipal service, despite the fact that they rarely implemented the services outlined in the Ordinance 002. A myriad of national laws promoting small businesses contributed to an ambiguous portrayal of street vending as an entrepreneurial activity The Supreme Decree 005 of 1991 recognized vending as a legitimate occupation but did not have a clear application in municipal law. The 1995 Law of Microenterprise and the Law of Employment Promotion indirectly included street vendors as the definitions involved selfemployed population with a small revenue. And locally, the Municipal Ordinance 082 for the sanitary control of food vending in the same year defined street trade as the activity carried out in regulated spaces but under the heading of "informal commerce."

Furthermore, the Constitutional Court rulings about cases of evicted street vendors in Lima further reinforced the legalist definition of street trade's informality. In all, 18 out of 20 street vendors' collective claims during 2005-2007 were declared unfounded (Roever and Aliaga Linares, 2008). The sentences declared that the duty of municipalities to regulate public space prevail over street vendors' right to conduct business in public space. As entrepreneurs, street vendors could not claim the constitutional right to work but that of free enterprise. As described in the compilation of Constitutional Court sentences:

Even though informal traders have the right to develop their activity protected by the right to free enterprise, this right must be exercised respecting others rights and the law (Eto, 2014, p. 52).

The shift toward redefining street trade as entrepreneurship contributed to fragment the base of organized street vendors. FEDEVAL and FEVACEL lost influence, and those vendors organized in cooperatives or associated in organizations promoting relocations concentrated in solving issues on case-by-case basis.

In Bogotá, the emphasis was not based on a reinterpretation of the economic activity but by the local redefinition of the municipality functions and duties related to the regulation of public space. As noted by Donovan (2002), a plethora of resolutions and added offices 
institutionalized the city's duty to recover public space. The 1991 Constitution explicitly stated as a function of government the defense of public space, and the 1993 Presidential Decree 1421 gave mayors the mandate to recover public space. In 1995, Mayor Antanas Mockus relaunched the FVP. The FVP was no longer an office with the sole purpose to develop programs for street traders, but added to its functions the defense of public space and the development of programs to coordinate the recovery of public space affected by street trade. By 1999, a Public Defender's Office for Public Space and an urban space police force were added to the institutional make-up of the city to facilitate confiscation of street vendors' merchandise and off-street relocations.

Without an explicit interpretation of street vendors as economic actors, street vendors' use of public space conformed to the "extra-legal" definition of the legalist approach. If the city duty was to defend public space, then street vending could not become a regulated economic activity. Under a process labeled "Pedagogical urbanism" (Berney, 2011), the mayor aimed at promoting "proper" public behavior, but defined as deviant uses of public space for the most vulnerable populations such as the homeless and street vendors (Galvis, 2014). As Antanas Mockus declared in an interview:

Since the 1994 electoral campaign, in which I competed against Peñalosa, I characterized public space as a sacred space; he also incorporated that idea, together we used it, understanding that everybody's quality of life depend a lot on the spaces we share, the shared infrastructure of public transport, the sidewalks, etc. It can be understood that public space is the extension and the secularization of church's space, where nobody will think to install market stalls or to robe. Keep in mind that Jesus evicted the traders in the temple (Negron, 2004).

Bogotás street vending organizations longstanding ideological alliances with left parties weakened with the discrediting of traditional political parties. The siege of the Palace of Justice by the M-19 guerrilla in 1985 further disconnected street vendors from left-leaning unions. As noted by Cely (1996), the number of street vendors' organizations grew to 165 in 1996 but organized around products of sale rather than associating with citywide politicized organizations. He also noticed that street vendors' demands diversified beyond the need to obtain licenses requesting business training and credit - services that were rarely offered within these citywide organizations (Cely, 1996, pp. 13, 25).

In both, Lima and Bogotá, citywide street vendors' organizations weakened by the emphasis on relocation policies. The dismantling of licenses in Bogotá and the discretionary practice by which local governments in Lima collected sisa left street vendors' claims to public space with no local legal basis. In contrast to the 1970s and 1980 s, the number of street vendors decreased dramatically by the end of 1990s in both cities. In Lima, the 1994 Municipality Survey documented a total number of 182,167 street vendors based on municipal registration lists. By 1996, the Municipality Survey in Lima reported a total of 80,878 street vendors, and in 1997, the number reached a record low of 45,594 vendors. In Bogotá, using the Colombian National Household Survey, Encuesta Nacional de Hogares (ENH), DANE estimated 95,443 street vendors in 1992. By 1994, the number of street vendors was almost the same. However, from 1994 to 1996, when evictions were enacted, the decline represented a drop of almost 26,000 vendors (Melo Moreno, 2001, p. 18).

\subsection{The free market city and entrepreneur-centered approaches}

During the 2000s, the consolidation of free market policies in Latin America contributed to a clearer intent of national and local authorities to direct policies toward informal self-employment or small entrepreneurship and decentralization allowed local municipalities to increase their enforcement capabilities to manage public space. Moreover, as the economy promotes private national and foreign investment, the commercial distribution channels
Paradoxes of informalizing street trade

661 
IJSSP

$38,7 / 8$

662

have become more favorable to large retailers and supermarkets. As a result, the role of street trade, despite research showing its links to formal retail channels and products, has been perceived as less central to the provision of the city.

In this context, the judiciary or constitutional courts had become critical actors in distinguishing the status of street vendors. In Lima, the constitutional rulings continued to solidify the idea of street vendors as informal entrepreneurs reinforcing local authorities' treatment of street trade within the legalist approach of the informal economy. In contrast, Colombia's constitutional court rulings shifted Bogotás local policies in favor of street vendors' right to work at streets and have incorporated the renewed dualist approach of the informal economy. Yet, this interpretation still departs from an image of street vendors as failed entrepreneurs in need of an upgrade through planned control. In both cities, the increased control has translated in new forms of marginal street vending.

4.3.1 Lima's neoliberal consolidation. From 2003 to 2010, relocation projects continued with Mayor Luis Castañeda but adopted a renewed and wider framework. The program Capitalizando instituted mandatory savings for all street vendors within Lima's downtown district or Cercado de Lima. The policy expanded to specialty vendors that had one-year renewable licenses within a restricted quota. To renew licenses, street vendors needed to be registered in the program. City officials offered training and supervised closely street vendors' savings to promote faster capitalization. Within these programs, licensed vendors are expected to relocate after two or three years. Other municipalities also implemented similar programs. For instance, public officials in Comas registered all street market associations and unorganized street vendors in a census and established a minimum amount of monthly savings overseen by requesting a copy of street vendors' bank account statements. Public officials defend that these programs on the grounds that they facilitate better economic conditions for street vendors. As, the Capitalizando officer in downtown Lima, affirms:

Our idea is to formalize those who are on the streets. What do I gain by giving them nicely painted stalls and pretty uniforms if they will continue to be on the streets? I want for this gentleman or lady to become a business-owner, to leave the street, and to install his or her business in a mall or a store. I want him or her to leave the subsistence economy and move to a prosperous economy of economic growth, because you have to think that the number of authorizations needs to be declining every day. That is the way I will measure the outcomes of my program, not only by those who are in the program but with the decreasing number of those on the streets, isn't it right? (Capitalization officer, Lima downtown, Author's translation).

Even though, public officials conceive these programs as a step in assuring formalization, there is no consistent evidence to suggest that relocations are conducive to economic growth or better working conditions. Based on a five year follow-up survey within two medium and two large relocated agglomerations perceived as successful, vendors reported having lost money between periods that lasted from three to six months but recovered their gains later (Guerrero, 2001). If roofed markets were a step forward in formalization and economic growth, their working conditions should be far superior to those of street vendors. Although estimations from ENAHO show that monthly earnings for market traders on average double those of street vendors, their hourly earnings do not differ significantly. The monthly advantage is largely due to the longer working hours of market traders compared to those of street vendors. Moreover, the majority of market traders are not registered for taxes and are less likely to have health insurance (Aliaga Linares, 2017). Additionally, the 2016 Census of Wholesale Markets in Peru revealed that almost half do not have adequate basic infrastructure to operate (INEI, 2017). It is obvious, therefore, that precarious working and environmental conditions moved from open-air to indoor markets. 
It is also unlikely for this type of formalization strategy to be sustainable overtime. In contrast to previous decades, access to land has become more costly to vendors even in peripheral neighborhoods. Calderón (2004, pp. 12-13) noted that legalizing property in the informal sector has not increased demand for existing housing; rather, it is small entrepreneurs who potentially expand the demand but for commercial use. Therefore, street vendors are more exposed to speculation when purchasing properties than in the past. For instance, a street market in Collique-Comas has developed associative savings for almost ten years. Since, most of the area is residential and poor, vendors have purchased four individual houses paying ten times the value of each of them. To be able to build their market, they expect to buy the whole block over the years, but each house becomes more costly as they continue to buy properties[10].

Despite sparse success stories reported on upward mobility among street vendors, the evidence of these policies is still mixed or inconclusive for the larger population. Moreover, as the pipeline from street markets to roofed markets has forcibly accelerated, the transition from peddler to fixed-post vendors has been disrupted by the restriction of licensing, the inconsistency of sis a collection and the increase in police control. In 2005, there were on average 35 police control operations against street vendors per municipality. For the period 2007-2010, this average increased to 181 (Aliaga Linares, 2017). As a result, the amount of precarious forms of street vending has increased with no substantial decreases in the number of street vendors. Between 2002 and 2009, the population working as street vendors in Lima oscillated around 200,000 with significant changes in their internal composition. The population of market traders has increased during times when the population of fixed or improvised stall vendors declined. Yet, the increases in the number of market traders did not absorb the decline of fixed or improvised stall vendors in large proportions. For instance, between 2008 and 2009, there was a decline of 13,340 fixed or improvised stall vendors but an increase of only 3,320 market traders. Peddlers, currently, represent 85 percent of Lima's street vendors compared to 76 percent in 2002.

The steady increase of peddling in Lima shows that the current policy framework leave much room for ungoverned public space. Unlicensed peddlers are rarely eligible for formalization programs and routinely face multiple incidents of municipal police abuse. From 2001 to 2006, the People's Defense Office, Defensoria del Pueblo, has received 72 claims of authority abuse among the different municipalities of Lima, 32 of them including testimonies of physical harm taking place in the historic center (Torres, 2007). Despite the claims, most municipalities neither incorporate peddlers in their policy planning toward street vendors nor implement preventive actions to avoid human rights' violations.

4.3.2 Bogotá's progressive shift. The Resolution 772 of the Constitutional Court in 2004, which ruled in favor of formerly evicted street vendors, mandated that the city of Bogotá implement a more comprehensive approach than off-street relocations. This resolution judged that evictions violated street vendors' right to work and earn a livelihood. It also mandated that the city administration stop confiscating street vendors' merchandise and implement policies that could assure evicted vendors with an alternative form of employment that could secure them at least a minimum wage.

The mandate was issued when Luis Garzón, a left-wing leader with a unionist background from Polo Democratico party, took office. Based on Law 9 Article 7 of 1989 that governs municipal planning and development and which recognized the economic use of public space - ignored by previous administrations, the Mayor enacted Decree No. 98 in 2004 which included several proposals to regulate the conditions to incorporate street vendors' use of public space in city planning. As a first step, the former FVP was
Paradoxes of informalizing street trade

663 
IJSSP

$38,7 / 8$

664 reconverted into the Institute for the Social Economy, Instituto para la Economía Social (IPES) in 2005. IPES conducted several studies to determine different approaches to upgrade street vendors' working conditions, particularly those who were protected by the Resolution of the Constitutional Court. IPES required street vendors to sign agreements, as a way to exchange street trade for access to one of their operating programs, which included limited-term vending in government-sponsored fairs, temporal employment, educational training, financial assistance or start-up funds for businesses. Street vendors were selected for each program according to their socioeconomic profiles[11].

Similar to previous zoning practices in the 1970s, the Garzón administration mapped and categorized zones of intervention. It divided the streets into three types of zones: transitory, recovered and special zones, with different implications for control and policy intervention according to Decree 98 of 2004 . The recovered spaces were those areas which were either taken by force or given voluntarily by vendors to the city in previous administrations. The special zones correspond to areas where public services such as the Cadastral Service, police posts, penitentiaries and other health or educational institutions are located and where vending is strictly prohibited. The Metropolitan police also will monitor special zones, and local inspector will follow-up on affected street vendors. In all these zones, the confiscation of vendors' merchandise is permitted by decree. Additionally, the city administration created "transitory zones" in the Plan Maestro del Espacio Público enacted by Decree No. 215 of 2005. Transitory zones are declared when vendors, through their organizations, sign agreements with IPES to access upgrading programs to return the public spaces in an agreed time frame. To ease traffic and order, vendors receive covered stalls that are removable, popularly called casetas. By Decree No. 419 of 2006, the inventory of spaces was approved by the Public Space Defenders Office, Defensoria del Espacio Público (DADEP).

To organize vending within current and prospective centralities, IPES created two urban planning projects: Analogue Spaces, Espacios Análogos, which was not yet implemented at the time of study, refers to the creation of built-in marketplaces on empty lots, passages or areas with estimated large pedestrian flows. The Pedestrian Service Network, Red de Servicios al Peatón (REDEP), constitutes a going back to the practice of renting quioscos or city run stalls for only certain type of goods, such as newspapers or snacks, from authorized providers. DADEP and the Instituto de Desarrollo Urbano (IDU) approved the locations for the REDEP stalls. The IPES selected from among registered vendors the beneficiaries of REDEP stalls. Up to 2010, of the 2,600 REDEP stalls projected, 304 (608 spots for sale) were installed within the local municipalities of Santa Fe, Candelaria, Antonio Nariño and Chapinero.

While IPES policies do not differ greatly from those implemented previously by FVP, they not only bring a new institutional management with other planning institutions but also the regulatory intent to graduate the vendor. For instance, REDEP participants are expected to leave their stalls after three years, in which they are also expected to save on average 300,000 Colombian pesos monthly (roughly US\$150) in order to start a new business. Interestingly, in a city that has shaped street vending as a mobile practice, effective control relies on offering limited stationary options in the understanding that vendors use them only temporarily.

Interestingly, the justification of need to look for alternative ways to secure employment has also involved a textual and consistent introduction to the label of informal in current rulings and local ordinances. Out of the 20 different decrees and resolutions issued from 2003 to 2010 about street vendors, 14 specifically attach the word "informal" to stationary or itinerant vending[12]. The added dimension of street trade's informality seem to validate the view that street vending must be a temporary employment situation, that is justified only as means to move out of poverty. 
Upgrading vendors' working conditions in Bogotá has entailed a large investment in exchange options for vendors with limited results in terms of the recovery of public space. The budget assigned to this process from 2004 to 2006 was almost four times larger than that of the period 2001-2003. Yet, the number of square meters of public space recovered for that period represented two-thirds of the number of public spaces recovered in the period 2001-2003. The large investment of these programs seem to put an unjustifiable weight on defending public space through the control of street vendors. According to DADEP, complaints related to street vending went down from 15 percent in 2003 to 1 percent in 2007, making established businesses a larger share of those restricting pedestrian use of public space.

Bogotá's policies may suggest an increasing trend toward regulated forms of street trade that could compensate either the decrease of stationary/fixed-post vendors or peddlers in the city. However, the results also go against these intended outcomes. As of 2007, Bogotá have approximately 67,000 street vendors[13], being 77 percent self-employed. Relative to 2003, the number of self-employed street vendors decreased by around 30,000. Similar to Lima, peddlers represent the highest proportion (85 percent) of vendors in Bogotá but unlike Lima, the decrease of street vendors is the sharpest among peddlers. This decrease did not compensate the increase of either stationary/fixed stall vendors or vendors in regulated stalls.

\section{Conclusions and implications}

Even though the discussion regarding the analytical flaws of the informal economy definition has faded over time, scholars have recently contested the use of the informal economy framework in street trade research (Bromley, 2000; Morales, 1997). They argue that the emphasis on the "unregulated" excludes from the analysis the political process by which different social institutions contribute to construct the "standards" set by law (Cross and Peña, 2006; Morales, 2001). Departing from the literature that emphasizes the politics of enforcement (Cross, 1998b; Holland, 2015; Cuvi, 2016), this paper takes a step forward by analyzing policy framing; that is, how city governments have aligned street trade policies with the competing perspectives of the informal economy used in the international and national development agenda. It has examined the many contextual factors that have made possible this alignment, such as the expansion of modern retail, increased political capabilities and resources for local enforcement, a higher state integration between local governments and judiciary resolutions, as well as multi-scalar connections with international development organizations.

An important contribution is that two distinct urban policy regimes, which rely on divergent informal policy approaches, converge at building a regulatory framework that decouples the right to work from the right to claim access to public space. As street trade becomes an informalized occupation, it becomes perceived as a form of substandard employment in need to be upgraded out of the streets. Compared to Lima's legalist focus, Bogota's dualist and structuralist approaches made this city more rights-oriented. Yet, this does not make a substantive difference in terms of the informalization and marginalization of street sellers. Therefore, in these apparently antagonistic approaches, the assessment of informality has served to validate interventions aimed at best economically integrate street vendors but without recognizing them as legitimate users of public space. These findings contradict general assumptions that may have equated socialist or progressive urban policy regimes with proactive inclusive policymaking, or neoliberal urban policy regimes with exclusionary outcomes. Either by formalizing street vending or upgrading options to trade, both approaches have used the binary of "informal/formal," relying in malleable theorizations, to justify local governments' increasing surveillance of public spaces, making street vendors even more elusive to the reach of regulation.
Paradoxes of informalizing street trade 
IJSSP

$38,7 / 8$

666

The failed formalization or upgrading attempts of both of these city experiences should invite policymakers to revisit their assessment of street trade as an employment problem. Ultimately, all occupations exist because of the need to work, but, even the least desirable occupations become viable employment options when they have a role to play in their corresponding social contexts. Beyond street trade role as source of employment, the literature on street trade in Latin America and elsewhere is still scant when it comes to empirical analysis and evidence-based research on street trade role in economic development, walkability, crime or neighborhood revitalization (Wongtada, 2014).

Perhaps it is too late to abandon the "informal" label, after all many grassroots organizations have been able to scale up through these international debates. Nevertheless, scholars should direct their attention to how these debates translate into local policies and have concrete consequences in framing local interventions toward vulnerable urban occupations. In that regard, we should move past the categorization of the "unregulated" and the emphasis on "compliance," to analyze the social and political process that create occupation-specific detrimental regulatory environments and social outcomes[14]. Otherwise, as scholars, we will be contributing to the persistent discourse of "othering" rather than untangling the political forces that shape the delegitimization and marginalization of disempowered citizens.

\section{Notes}

1. Recent estimates from 11 cities across West Africa, Southeast Asia and South America show that street trade is not the largest informal-worker group but it is a predominant female occupation. At least in eight of these cities, women outnumber men in street vending. However, women also represent the highest share of informal home-based workers in at least seven of these cities (see Herrera et al., 2012).

2. As described by Chen (2012), there are four dominant theories with different diagnoses and prognoses about informality. The dualist perspective defines the informal sector as marginal activities comprising survival strategies in need of support services. The structuralist defines the informal economy as unregulated economic activities but it emphasizes the subordination of economic units to capitalist development as the primary cause for their expansion. Therefore, structuralists call for equitable policies to subvert intrinsic inequalities in the labor market. The legalist perspective blames over-regulation, and advocates for administrative simplification. And the voluntarist defends that non-compliance is a dominant factor that manifest either in scenarios of exclusion and choice and that government should address unfair competition. It is important to note that there are alternative regional perspectives. For instance, the economia popular or solidaria is also a dominant school of thought in Latin America. These perspectives challenges the default assumption that all economic activity has a for-profit logic. It advocates for more humane forms of economic organizations using the principles of cooperation and reciprocity. However, these regional perspectives have rarely been influential city-wide and had only a supplementary role for promoting cooperatives or other associative initiatives among informal workers.

3. For instance, household economies depended on a stable but low-wage incomes of at least one family member to maintain informal economic activities, and unemployment affected to sustain these activities more effectively (see Gonzalez de la Rocha, 2004).

4. In 1965, the state managed to build one market for every five markets built by street-vendor associations. This ratio increased to one state-built market for every 12 street vendors-built markets in 1985 (De Soto et al., 1986, p. 91).

5. As capital cities of countries that have experienced high economic growth between 2000 and 2010, Lima and Bogotá only had slight reductions in informal sector employment and maintained moderate levels of residential segregation. In 2008, 55.8 percent of Lima's working population 
was employed in the informal sector, representing a drop of 7 percent points compared to 2000 (MTPE, 2009). Similarly, between 2001 and 2007, Bogotá's share of informal sector employment decreased modestly from 54.6 to 50.8 percent (Gutierrez et al., 2010).

6. In the case of residential segregation, Lima and Bogotá have moderate residential segregation indexes compared to other Latin American cities, the highest being Santiago with a dissimilarity index of 0.41 and lowest being Mexico City with a dissimilarity index of 0.14 (Roberts and Wilson, 2009). From the 1993 census to the 2005 census, Bogotá's dissimilarity index remained at 0.25 , estimating that only a quarter of the low socioeconomic households will need to move to reach an even distribution thorough the city (Aliaga Linares and Alvarez-Rivadulla (2010). Lima's dissimilarity index for 1993 at 0.33 is higher than that of Bogotá's. And while recent comparable estimates are not publicly available, most experts coincide that the levels have not changed dramatically in the 2007 census (Pereyra, 2006).

7. For Lima-Perú, I used the Encuesta Nacional de Hogares (ENAHO) for the years from 2002 to 2009. For Bogotá-Colombia, I used the Encuesta Calidad de Vida (ECV) for the years 2003 and 2007.

8. The rise of street markets that sold smuggled goods such as clothing or appliances such Polvos Azules in Lima or San Andresito in Bogota illustrates this trend in both cities.

9. As quoted by Osterling and Chavez, brochures and other documents such the call to support to strikes disseminated by FEDEVAL in 1979 equated the conditions of street vendors similar to those of farm labor and factory workers.

10. Interview with Ninon Castillo, street vendor leader, July 6, 2009.

11. For instance, young vendors were offered temporary employment and educational training, and elder vendors were offered access to government-sponsored artisan fairs.

12. Authors' estimations based on compiled legislations available at the Secretaria de Gobierno website. Within the six resolutions not using the word informal four related to REDEP beneficiaries and two from the Institute of Sports and Recreation regarding requirements for food vending around parks.

13. ECV does not provide detailed codes for street vendors. Therefore, a combination of people working as sales person was used in conjunction to those that reported working at streets to identify street vendors. In order to compare this trend to Lima, the sample include only self-employed people.

14. Harriss-White (2017) in her analysis of Indian wastepickers also emphasized that the informal economy is more a political process than a binary state.

\section{References}

Alessio, N. (1970), “Urbanizacao, industrializacao e estructura occupacional (1872-1920)”, Dados, No. 7, pp. 103-117.

Aliaga Linares, L. (2017), "Statistics on street vendors and market traders in Metropolitan Lima and Urban Peru”, Women in Informal Employment Globalizing and Organizing, WIEGO Statistical Brief No. 16, Manchester.

Aliaga Linares, L. and Alvarez-Rivadulla, M.J. (2010), "Residential segregation in Bogota across time and scales", Lincoln Institute of Land Policy, Cambridge, MA.

Benjamin, N., Beegle, K., Recanatini, F. and Santini, M. (2014), "Informal economy and the World Bank", Policy Research Working Paper No. 6888, The World Bank, Washington DC.

Berney, R. (2011), "Pedagogical urbanism: creating citizen space in Bogota, Colombia”, Planning Theory, Vol. 10 No. 1, pp. 16-34.

Biles, J.J. (2009), "Informal work in Latin America: competing perspectives and recent debates", Geography Compass, Vol. 3 No. 1, pp. 214-236.
Paradoxes of informalizing street trade 
Breman, J. (1976), “A dualistic labour system? A critique of the 'Informal Sector' concept”, Economic and Political Weekly, Vol. 11 No. 48, pp. 1870-1876.

Bromley, R. (1978), "Organization, regulation and exploitation in the so-called 'Urban Informal Sector': the street traders of Cali, Colombia”, World Development, Vol. 6 Nos 9/10, pp. 1161-1171.

Bromley, R. (2000), "Street vending and public policy: a global review", International Journal of Sociology and Social Policy, Vol. 20 Nos 1/2, pp. 1-28.

Caldeira, T.P.D.R. (2000), City of Walls: Crime, Segregation, and Citizenship in São Paulo, University of California Press, Berkeley, CA.

Calderón, J. (2004), "La formalización de la propiedad en el Perú. Efectos económicos y socio culturales", IV Seminario Internacional "Innovando los procesos de acceso al suelo urbano". UNAM-PUECLincoln Institute.

Cameron, M. (1991), "The politics of the urban informal sector in Peru: populism, class, and 'redistributive combines', Canadian Journal of Latin American and Caribbean Studies, Vol. 16 No. 31, pp. 79-104.

Castañeda, A. and Garcia, J. (2007), Hábitat y Espacio Público: El caso de los Vendedores Ambulantes en el Espacio Público Físico de Bogotá, Alcaldía Mayor de Bogotá, Secretaria de Gobierno, Instituto para la Economía Social, PNUD-UN Habitat, Bogotá.

Castells, M. and Portes, A. (1989), "World underneath: the origins, dynamics, and effects of the informal economy", in Portes, A. (Ed.), The Informal Economy: Studies in Advanced and Less Developed Countries, John Hopkins University Press, Baltimore, MD, pp. 11-37.

Cely, J.N. (1996), Organizaciones del sector informal en Bogotá: perfil y diagnóstico, International Labor Organization, Bogota, DC.

Chavez, E. and De la Flor, R. (1998), "El nuevo rostro de la vieja urbe: Comercio ambulatorio y recuperación del centro histórico de Lima”, in Chavez, E. (Ed.), Perú: El Sector Informal Frente al Reto de la Modernización, International Labour Organization, Geneva, pp. 123-174.

Chen, M.A. (2007), Rethinking the Informal Eocnomy: Linkages with the Formal Economy and the Formal Regulatory Environment, United Nations Department of Economic and Social Affairs, New York, NY.

Chen, M.A. (2012), "The informal economy: definitions, theories, and policies", Women in the Informal Economy Globalizing and Organizing, WIEGO Working Paper No. 1, Manchester.

Contreras, V. and Thomas, J. (1993), Surviving on the Street: The Ambulatory Street Traders of Santiago, ILO-PREALC, Santiago de Chile.

Cross, J. (1998a), "Co-optation, competition, and resistance - state and street vendors in Mexico city", Latin American Perspectives, Vol. 25 No. 2, pp. 41-61.

Cross, J.C. (1998b), Informal Politics: Street Vendors and the State in Mexico City, Stanford University Press, Stanford, CA.

Cross, J. and Peña, S. (2006), "Risk and regulation in informal and illegal markets", in Fernández-Kelly, P. (Ed.), Out of the Shadows: Political Action and the Informal Economy in Latin America, Pennsylvania State University Press, University Park, PA, pp. 49-80.

Crossa, V. (2009), "Resisting the entrepreneurial city: street vendors' struggle in Mexico City's Historic Center", International Journal of Urban and Regional Research, Vol. 33 No. 1, pp. 43-63.

Cuvi, J. (2016), "The politics of field destruction and the survival of São Paulo's street vendors”, Social Problems, Vol. 63 No. 3, pp. 395-412.

De Soto, H. (2002), "Informal trade", The Other Path: the Economic Answer to Terrorism, 1st ed., Harper \& Row, New York, NY, pp. 59-92.

De Soto, H., Ghersi, E. and Ghibellini, M. (1986), El Otro Sendero: La Revolución Informal, Instituto Libertad y Democracia, Editorial Barranco, Lima.

Donovan, M.G. (2002), "Space wars in Bogota: the recovery of public space and its impact on street vendors", MA thesis, Massachussets Institute of Technology, Boston, MA. 
Donovan, M.G. (2008), “Informal cities and the contestation of public space: the case of Bogota's street vendors, 1988-2003”, Urban Studies, Vol. 45 No. 1, pp. 29-51.

Eto, G. (2014), Treinta años de jurisdicción constitucional en el Perú, Tribunal Constitucional, Centro de Estudios Constitucionales, Lima.

Evans, M. (2005), "Reubicación del comercio ambulatorio en Lima Metropolitanta y el papel de las organizaciones (1996-2002)”, in Evans, M. and Pisfil, E. (Eds), Desalojo y reubicación del comercio ambulatori en las ciudades de Lima y Truïllo, EDAPOSPO-COPEME, Lima, pp. 13-154.

Galvis, J.P. (2014), "Remaking equality: community governance and the politics of exclusion in Bogota's public spaces”, International Journal of Urban and Regional Research, Vol. 38 No. 4, pp. 1458-1475.

Garcia Rincon, M.F. (2010), “Governance of street trade in Caracas, Venezuela”, in Browmik, S.K. (Ed.), Street Vendors in the Global Urban Economy, Routledge, Oxon, pp. 241-255.

Germani, G. (1968), Politica y Sociedad en una época de transición, Paídos, Buenos Aires.

Ghersi, E., Alonso, I. and Iwasaki, G. (1998), El Comercio Ambulatorio en Lima Metropolitana, Instituto Libertad y Democracia, Lima.

Goldfrank, B. and Schrank, A. (2009), "Municipal neoliberalism and municipal socialism: urban political economy in Latin America”, International Journal of Urban and Regional Research, Vol. 33 No. 2, pp. 443-462.

Gonzalez de la Rocha, M. (2004), “De los 'Recursos de la Pobreza' a la 'Pobreza de Recursos' y a las 'Desventajas Acumuladas'”, Latin American Research Review, Vol. 93 No. 1, pp. 192-195.

Guerrero, E. (2001), De Ambulantes a Empresarios: Reubicación y Reordemaniento del Comercio Ambulatorio, NGO Alternativa-DESCO, Lima.

Gutierrez, D.C., Uribe, M.C., Martinez, J. and Florez, A. (2010), Evolución del Mercado Laboral de Bogotá 2001-2009. Perspectiva de Absorción y Calidad del Empleo en Bogotá, Secretaria Distrital de Planeación, Bogota, DC.

Harriss-White, B. (2017), "Formality and informality in an Indian urban waste economy", International Journal of Sociology and Social Policy, Vol. 37 Nos 7/8, pp. 417-434.

Hart, K. (1973), "Informal income opportunities and urban employment in Ghana”, Journal of Modern African Studies, Vol. 11 No. 1, pp. 61-89.

Herrera, J., Kuépié, M., Nordman, C.J., Oudin, X. and Roubaud, F. (2012), "Informal sector and informal employment: overview of data for 11 cities in 10 developing countries”, Women in the Informal Economy Globalizing and Organizing, Cambridge, available at: www.wiego.org/sites/wiego.org/ files/publications/files/Herrera_WIEGO_WP9.pdf

Hirth, K.G. and Pillsbury, J. (2013), Merchants, Markets, and Exchange in the Pre-columbian World, Dumbarton Oaks, Washington, DC.

Holland, A.C. (2015), "The distributive politics of enforcement”, American Journal of Political Science, Vol. 59 No. 2, pp. 357-371.

Holland, A.C. (2016), "Forbearance”, American Political Science Review, Vol. 110 No. 2, pp. $232-246$.

Hunt, S. (2009), “Citizenship place: the state's creation of public space and street vendors' culture of informality in Bogotá, Colombia”, Environment and Planning D: Society and Space, Vol. 27 No. 2, pp. 331-351.

ILO (2015), "Recommendation concerning the transition from the informal to the formal economy ", No. 204, adopted by 104th International Labour Conference Session, Geneva.

ILO (2016), The Regulatory Framework and the Informal Economy Specific Groups: Street Vendors', International Labour Office, Geneva.

INEI (2017), Censo Nacional de Mercado de Abastos 2016, Instituto Nacional de Estadistica e Informática, Ministerio de la Producción, Lima.

Lambert, D. (1965), "L'urbanisation accélérée de l'Amerique Latine et la Formation d'un secteur tertiaire refuge”, Civilisations, Vol. 15, pp. 150-174.
Paradoxes of informalizing street trade 
Lanzetta de Pardo, M., Murillo Castaño, G. and Triana Soto, A. (1988), "The articulation of formal and informal sectors of the economy of Bogotá, Colombia”, in Portes, A. and Castells, M. (Eds), The Informal Economy: Studies in Advanced and Less Developed Countries, John Hopkins Press, Baltimore, MD, pp. 95-110.

Lyons, M. and Titus Msoka, C. (2010), “The world bank and the street: (How) Do 'Doing Business' reforms affect Tanzania's Micro-traders?”, Urban Studies, Vol. 47 No. 5, pp. 1079-1097.

Maloney, W.F. (2004), “Informality revisited”, World Development, Vol. 32 No. 7, pp. 1159-1178.

Mazumdar, D. (1976), “The urban informal sector”, World Development, Vol. 4 No. 8, pp. 655-679.

Melo Moreno, V. (2001), La Calle: Espacio Geográfico y Vivencia Urbana en Santa Fé de Bogotá, Instituto Distrital de Cultura y Turismo, Bogotá.

Mitullah, W. (2003), "Street vending in African cities: a synthesis of empirical findings from Kenya, Cote D'Ivoire, Ghana, Zimbabwe, Uganda and South Africa”, World Development Report background papers, World Bank, Washington, DC.

Morales, A. (1997), "Epistemic reflections on the informal economy", The International Journal of Sociology and Social Policy, Vol. 17 Nos 3/4, pp. 1-17.

Morales, A. (2001), "Policy from theory: a critical reconstruction of theory on the 'Informal Economy'", Sociological Imagination, Vol. 38 No. 3, pp. 190-203.

Moralo Camargo, F. (2010), "El Paro Civico Nacional del 14 de Septiembre de 1977 en Bogotá: Las Clases Subalternas contra el modelo hegemónico de ciudad”, Revista Ciudad Paz-Ando, Vol. 3 No. 2, pp. 111-142.

Moser, C. (1978), "Informal sector or petty commodity production: dualism or dependence in urban development?”, World Development, Vol. 6 Nos 9/10, pp. 1041-1064.

Moser, C. (1980), "Why the poor remain poor: the experience of Bogota market traders in the 1970s", Journal of Internamerica Studies and World Affairs, Vol. 22 No. 3, pp. 365-387.

MTPE (2009), El Empleo en Lima Metropolitana 2008. Informe Anual, Ministerio de Trabajo y Promoción del Empleo, Lima.

Negron, M. (2004), "Nuestra estrategia fue cambiar primero la mentalidad y luego la infrastructura. Entrevista a Antanas Mockus, Ex-alcalde de Bogotá”, COINDUSTRIA, Planum Magazine, available at: www.planum.net/nuestra-estrategia-fue-cambiar-primero-la-mentalidad-y-luego-lainfraestructura

Nelson, N. (1992), "Public order and private entrepreneurs: the pocket economy of street vending in Bogota”, University of New Mexico, Colombia.

Nun, J. (1969), "Superpoblación relativa, ejecito industrial de reserva y masa marginal", Revista Latinoamericana de Sociología, Vol. 5 No. 2, pp. 178-236.

Nuñez Castrejón, A. and Gómez Chiñas, C. (2008), Controversia y debate actual sobre el sector informal, (Universidad Autónoma Metropolitana-Unidad Azcapotzalco54), Mexico City.

Osterlling, J.P. and Chavez de Paz, D. (1979), "La Organización de los Vendedores Ambulantes: El Caso de Lima Metropolitana”, Revista de la Universidad Católica, No. 6, pp. 185-202.

Papola, T.S. (1980), "Informal sector: concept and policy”, Economic and Political Weekly, Vol. 15 No. 18, pp. 817-824.

Peattie, L. (1987), “An idea in good currency and how it grew: the informal sector”, World Development, Vol. 15 No. 7, pp. 851-860.

Pereyra, O. (2006), "Forma urbana y segregación residencial en Lima”, Debates en Sociologia, No. 31, pp. 69-106.

Perlman, J.E. (1976), The Myth of Marginality: Urban Poverty and Politics in Rio de Janeiro, University of California Press, Berkeley, CA.

Perry, G., Maloney, W.F., Arias, O.S., Fajnzylber, P., Mason, A.D. and Saavedra, J. (2007), Informality: Exit and Exclusion, The World Bank, Washhington, DC. 
Pinto, A. (1970), Naturaleza e implicaciones de la 'heterogeneidad estructural' de la América Latina, Fondo de Cultura Económica145, Mexico City.

Portes, A. and Roberts, B.R. (2005), "The free-market city: Latin American urbanization in the years of the neoliberal experiment", Studies in Comparative International Development, Vol. 40 No. 1, pp. $43-82$.

Portes, A. and Schauffler, R. (1993), "Competing perspectives on the Latin American informal sector", Population and Development Review, Vol. 19 No. 1, pp. 33-60.

Prebisch, R. (1962), El desarrollo económico de América Latina y algunos de sus principales problemas, Comisión Económica para América Latina (CEPAL)1, Santiago de Chile.

Quijano, A. (1969), "Dependencia, Cambio Social y Urbanización en América Latina”, Revista Mexicana de Sociología, Vol. 30 No. 3, pp. 525-570.

Rakowski, C.A. (1994), "Convergence and divergence in the informal sector debate: a focus on Latin America, 1984-1992", World Development, Vol. 22 No. 4, pp. 501-516.

Roberts, B.R. and Wilson, R. (2009), Urban Segregation and Governance in the Americas, Palgrave MacMillan, New York, NY.

Roever, S. (2005), "Negotiating formality: informal sector, market, and State in Peru", PhD thesis, University of California, Berkeley, CA.

Roever, S. (2006), "Enforcement and compliance in Lima's street markets: the origins and consequences of policy incoherence toward informal traders", in Guha-hasnobis, B., Kanbur, R. and Ostrom, E. (Eds), Linking the Informal and Formal Economy: Concepts and Policies, Oxford University Press, Oxford, pp. 246-262.

Roever, S. (2010), "Street trade in Latin America: demographic trends, legal issues and vending organizations in six cities", in Bhowmik, S. (Ed.), Street Vendors in the Global Urban Economy, Routledge, New Delhi, pp. 208-240.

Roever, S. and Aliaga Linares, L. (2008), "Case report of Lima Peru prepared for International Labour Organization in India", unpublished manuscript.

Sabatini, F. (2006), The Social Spatial Segregation in the Cities of Latin America, Inter-American Development Bank, Sustainable Development Department, Washington, DC.

Salazar, G. (2004), Ferias libres: espacio residual de soberania ciudadana, Ediciones SUR, Santiago de Chile.

Sethuraman, S.V. (1976), "The urban informal sector: concept, measurement and policy”, International Labour Review, Vol. 114 No. 1, pp. 69-81.

Simanca Castillo, O. (2007), Historia Institucional del Fondo de Ventas Populares, Alcaldía Mayor de Bogotá D.C, Bogota, DC.

Sislen, D., Samad, T., Anthony, S., Haggarty, L. and Artemiev, I. (2007), “Agilización de los trámites burocráticos en Lima. Cómo se beneficia el clima de inversión con la simplificación municipal", En Breve, No. 99, Equipo de Gestión del Conocimiento de la División de Operaciones para la Región de América Latina, World Bank, Washington, DC, January.

Steel, G. (2008), Vulnerable Careers: Tourism and Livelihood Dynamics Among Street Vendors in Cusco, Peru, Latin America Research Series, Rozenberg Publishers, Amsterdam.

Teltscher, S. (1994), "Small trade and the world economy: informal vendors in Quito, Ecuador", Economic Geography, Vol. 70 No. 2, pp. 167-187.

Tokman, V.E. (1989), "Policies for a heterogeneous informal sector in Latin America", World Development, Vol. 17 No. 7, pp. 1067-1076.

Tokman, V.E. (1990), "Sector Informal en América Latina: De subterránero a legal", in Tokman, V.E. (Ed.), Más allá de la Regulación: El sector informal en América Latina, PREALC, Santiago de Chile, pp. 3-23.

Torres, C. (2007), Denuncian abusos de serenazgo contra vendedores ambulantes, El Comercio, Lima. 
Williams, C.C. and Gurtoo, A. (2012), "Evaluating competing theories of street entrepreneurship: some lessons from a study of street vendors in Bangalore, India", International Entrepreneurship and Management Journal, Vol. 8 No. 4, pp. 391-409.

Wongtada, N. (2014), "Street vending phenomena: a literature review and research Agenda", Thunderbird International Business Review, Vol. 56 No. 1, pp. 55-75.

\title{
Further reading
}

ILO (1993), Resolution Concerning Statistics of Employment in the Informal Sector adopted by the 15th International Conference Of Labour Statisticians, Geneva.

ILO (2003), Guidelines concerning a statistical definition of informal ecmployment adopted by the 17th International Conference of Labour Statisticians, Geneva.

\begin{abstract}
About the author
Lissette Aliaga Linares is Assistant Professor of Sociology and a Senior Research Associate at the Center for Public Affairs Research at the University of Nebraska Omaha. She holds a MA and PhD in Sociology from the University of Texas at Austin, and completed her undergraduate studies at the Universidad Mayor de San Marcos in Lima, Peru. Her research focuses on the social construction of economic and urban informality in Latin America and the USA. Lissette Aliaga Linares can be contacted at: laliagalinares@unomaha.edu
\end{abstract}

For instructions on how to order reprints of this article, please visit our website: 